\title{
Behavioral and electrophysiological responses of Hylastinus obscurus to volatiles released from the roots of Trifolium pratense $\mathrm{L}$.
}

\author{
R. Palma ${ }^{1,2}$, A. Mutis ${ }^{1}$, L. Manosalva ${ }^{1,2}$, R. Ceballos ${ }^{3}$ and A. Quiroz ${ }^{1 *}$ \\ ${ }^{I}$ Center of Chemical Ecology of Terrestrial and Aquatic Systems, BIOREN-UFRO, Universidad de La \\ Frontera. Casilla 54-D, Temuco, Chile. ${ }^{2}$ Programa de Doctorado en Ciencias de Recursos Naturales, \\ Universidad de La Frontera, Casilla 54-D, Temuco, Chile. ${ }^{3}$ Centro Regional de Investigación INIA- \\ Quilamapu, Casilla 426, Chillán, Chile. ${ }^{*}$ orresponding author: aquiroz@ufro.cl
}

\begin{abstract}
Root volatiles from field-collected red clover plants, Trifolium pratense L., of five different ages were trapped by solid-phase microextraction (SPME) and analyzed by gas chromatography-mass spectrometry (GC-MS). Ethanol, E-2-hexenal, hexanal, 3 -octanone, limonene and $\alpha$-pinene were identified. The electroantennographic (EAG) and olfactometric responses of clover root borer, Hylastinus obscurus, to the identified compounds were studied. The GC-MS with SPME as a solvent-free collection method identified ethanol and hexanal compounds that have not previously been reported in T. pratense. The EAG experiments showed that all of the tested compounds were perceived by $H$. obscurus, but mixed responses were found in behavioral assays. For females, ethanol and $E$-2-hexenal were attractive at one or more of the tested doses, while hexanal, 3-octanone, $R$-limonene and $S$-limonene were repellent at one or more of the tested doses. Females responded to a larger number of tested compounds and a wider range doses compared to males. This behavior could reflect a more active role of females in host finding and colonization.
\end{abstract}

Keywords: Root volatiles, red clover, root borer, electroantennography, olfactometry, SPME. 


\section{Introduction}

Hylastinus obscurus (Coleoptera: Curculionidae: Scolytinae), commonly named red clover root borer, is an important pest of red clover crops, and infestation levels can reach $70 \%$ to $100 \%$ of the plants in pastures that are two to three years old (Aguilera et al., 1996). Just 1.5 borers per plant can cause a $5.5 \%$ reduction in forage yield (Pruess and Weaver, 1958). In addition, secondary effects appear because the borer opens an entrance for new pests and diseases. Thus, this insect is an important cause of red clover decay (Steiner and Alderman, 1999; 2003) and pesticide applications have not been successful for its control (Quiroz et al., 2005).

Red clover is the most important host of this pest, and this close plant-insect relationship has been studied previously. Past studies have reported that chemicals released by red clover plants play an important role in root borer behavior. The attractiveness of roots was demonstrated in behavioral assays using diseased-root leachate and diseased-root pieces (Leath and Byers, 1973). The attractiveness of volatiles from the aerial parts was also reported by Quiroz et al., (2005). With respect to the compounds, a number of chemicals found in the leaves, flowers and seed pods of red clover were suggested as possible insect attractants (Buttery et al., 1984), but only E-2-hexenal and methyl benzoate have been reported as attractants for red clover borer (Tapia et al., 2007). Finally, although the ages of the plants reported as attractive varied from 60 days (Tapia et al., 2005) to 2.5 years (Quiroz et al., 2005), Manosalva (2010) studied the extracts of roots of young plants of red clover and noted the attractiveness for $H$. obscurus to volatiles of plants that were 5, 7 and 9 months of age, whereas field studies have demonstrated that plants are colonized at 6 months of age (Alarcón et al., 2010).
Although the evidence points to a group of compounds involved in this insect-plant interaction, their electrophysiological activities and ubiquities have not yet been proved, particularly for plants of ages that are close to those at the beginning of infestation. In addition, all of the compounds that have been identified in roots have been collected using solvent-dependant methodologies, where the solvent can co-elute with valuable compounds of low polarity.

Solid-phase microextraction (SPME) has been reported as a simple and fast method to obtain fingerprints of plant headspace (Cornu et al., 2001). It uses a fused silica fiber with a polymeric coating to extract organic compounds from their matrix and directly transfer the analytes into a gas chromatograph (GC) by thermal desorption in a GC injector (Zhang and Pawliszyn, 1995). As a solvent-free technique, it offers the possibility to analyze highly volatile and/or trace compounds that cannot be easily disclosed by $\mathrm{GC}$ when organic solvents are used because they coelute with the solvent or are lost during concentration (Rochat et al., 2000).

The aim of the current work was to clarify the link between the volatiles released by red clover and their ability to elicit response in Hylastinus obscurus by studying the electrophysiological and behavioral response of clover borers to individual compounds identified from roots of different ages.

\section{Materials and methods}

\subsection{Insects}

Red clover plants collected from different plots located in the Regional Research Center INIA-Carillanca in Vilcún, Araucanía, Chile were brought to the laboratory. The researchers wore gloves and used tweezers 
to isolate the insects from their substrates and placed them in glass Petri dishes with fresh root pieces on humid filter paper; the dishes were held at $7{ }^{\circ} \mathrm{C}$ until use. To perform the bioassays, the insects were removed from the root pieces 12 hours before their use and placed in humid chambers consisting of glass Petri dishes with pieces of filter paper humidified with distilled water and held at $7{ }^{\circ} \mathrm{C}$. One hour before the experiments, the humid chambers were brought to room temperature. The individuals were used once, and their sex was determined after the bioassay, following the description made by Matamala (1976).

\subsection{Volatiles collection}

Clover plants (cv. Redqueli) of different ages were carefully collected from the same place noted before. In the laboratory, the aboveground parts were separated from the roots, which were gently washed with distilled water to remove the soil. The roots were then air-dried. Two grams of fresh roots from at least six plants was weighed and put into a $40-\mathrm{mL}$ glass vial with a PTFE septum at room temperature 30 minutes before beginning volatiles collection. For 60 minutes, the volatiles in the flask were trapped using an SMPE holder containing a $65-\mu \mathrm{m}$ polydimethylsiloxane/ divinylbenzene fiber (Supelco, USA). The volatiles were collected from the roots of red clover plants on the same day the plants were collected from the field.

\subsection{Chemical analysis and compounds determination}

The collected volatiles were analyzed by gas chromatography-mass spectrometry (GC-MS), injecting the fiber into a Thermo-Finnigan chromatograph (Milan, Italy) with electron impact ionization (70 $\mathrm{eV}$ ) equipped with a BP-1 capillary column (30 $\mathrm{m}$ in length by $0.22 \mathrm{~mm}$ by $0.25 \mu \mathrm{m}$; SGE, Victoria, Aus- tralia). Helium was used as the carrier gas, and the oven was programmed with $40^{\circ} \mathrm{C}$ as the starting temperature, ramping up to $240{ }^{\circ} \mathrm{C}$ at $5{ }^{\circ} \mathrm{C}$ per minute; the final temperature of $240{ }^{\circ} \mathrm{C}$ was held for 3 minutes. The temperatures in the injector and transfer line were $250{ }^{\circ} \mathrm{C}$.

The volatiles collected were identified by comparison of their mass spectra with those of commercial standards and library database spectra using the NIST mass spectral search program (ver. 2.0), Pherobase (http://www.pherobase.com) and the NIST webbook (http://webbook.nist.gov/chemistry), cited by Babushok et al. (2007).

\subsection{Chemical standards}

All of the chemicals used in the bioassays corresponded to chromatographic grade standards: ethanol (Merck, Darmstadt, Germany, 99.9\% purity), $R$ - $\alpha$-pinene (Merck, Munich, Germany, 97\% purity), $S$ - $\alpha$-pinene (Merck, Munich, Germany, 97\% purity), $S$-limonene (Sigma Aldrich, Steinheim, Germany, 96\% purity), $R$ limonene (Sigma Aldrich, Steinheim, Germany, 97\% purity), E-2-hexenal (Merck, Hohenbrunn, Germany, 96\% purity), hexanal (Aldrich, Steinheim, Germany, 98\% purity) and 3-octanone (Aldrich, Steinheim, Germany, $98 \%$ purity).

\subsection{Behavioral bioassays}

A Y-shaped glass tube was used as the arena; its arms and central tube were $55 \mathrm{~mm}$ long and $9 \mathrm{~mm}$ inner diameter (i.d.). To move the air from the arms to the base, a vacuum was applied at the end of the central tube at $0.2 \mathrm{~L} \mathrm{~min}^{-1}$. At the end of each arm, an odor cartridge was connected. These cartridges consisted of a glass tube of $9 \mathrm{~mm}$ outer diameter (o.d.) containing a paper strip $(8 \mathrm{~mm}$ by $60 \mathrm{~mm})$. Each strip was impregnated under the fume hood with $50 \mu \mathrm{L}$ 
of solution or hexane (control) and air-dried for $30 \mathrm{~s}$ before being placed inside the cartridge. Behind the odor cartridge, a charcoal filter was connected to ensure that clean air was entering the arena. An adult $H$. obscurus individual was introduced into the base of the Y-tube, and the vacuum tube was connected. Finally, the arm chosen by the borer was noted after 5 minutes or less. The assay was considered successful when the insect passed $10 \mathrm{~mm}$ beyond the $\mathrm{Y}$ tube bifurcation, but when the insect did not choose any arm, the assay was discarded. After the olfactometer assay, the insects were stored individually in labeled microcentrifuge tubes with ethanol for sex determination. At least 15 replications per sex were performed for each compound and dose. Furthermore, to ensure that the insects were not biased in their preferences, a complete set of experiments was done using hexane in both arms.

\subsection{Electroantennography}

The heads of adult insects were cut for electrode insertion using a scalpel and tweezers under a microscope. The electrodes consisted of silver wires inside of glass capillaries filled with $1 \mathrm{M} \mathrm{KCl}$ and $0.1 \% \mathrm{PVP}$ solution (Syed and Leal, 2007). The indifferent electrode was inserted at the base of the head, and the recording electrode was placed in contact with the tip of one of the antennae (Mendesil et al., 2009). The preparation was made on a Syntech MP-12 micromanipulator (Hilversum, The Netherlands) connected to a 10X amplifier. The signal was received by a Syntech IDAC-02 interface (Hilversum, The Netherlands), which was linked to a personal computer running the EAG software to collect and interpret the information. The preparation was allocated under a humidified and charcoal-filtered air flux, ca. $5 \mathrm{~mm}$ from the glass pipe outlet of $25 \mathrm{~mm}$ i.d., and a hole of $2.5 \mathrm{~mm}$ at $50 \mathrm{~mm}$ from the outlet was used to connect the odor cartridg- es. The tested compounds were applied to filter paper strips ( $8 \mathrm{~mm}$ by $50 \mathrm{~mm}$ ) using $10 \mu \mathrm{L}$ of a chemical standard. The strips were then placed inside $5-\mathrm{mL}$ disposable polypropylene syringes (Syed et al., 2003; Jeanbourquin and Guerin, 2007). The Syntech CS-05 stimulus controller (Hilversum, The Netherlands) was set to a continuous flow of $0.6 \mathrm{~L} \mathrm{~min}^{-1}$, while the stimuli were applied for 1 second at $0.7 \mathrm{~L} \mathrm{~min}^{-1}$. At least $45 \mathrm{~s}$ were allowed between the puffs, and the different odorants were tested in a random order but starting and finishing with ethanol puffs. Six replications were performed per sex and compound, using ethanol as the control.

\subsection{Analysis of data}

The relative EAG responses were analyzed by the Kruskal-Wallis test followed by the Conover-Inman test for multiple comparisons (Conover, 1999) using the StatsDirect statistical software v. 2.7.8 (StatsDirect Ltd., UK). The frequencies obtained in the olfactometer assays were analyzed by G-test for goodness of fit (Sokal and Rohlf, 2005).

\section{Results}

The GC-MS analysis of the samples obtained by SPME showed the presence of six compounds (Table 1): ethanol, hexanal, E-2-hexenal, $\alpha$-pinene, 3-octanone and limonene. No one single root sample showed all six of these compounds. E-2-hexenal appeared only in the 5-month-old roots, and limonene was detected only in the 6- and 24-month-old roots. 3 -octanone appeared at all of the different ages tested except 24-month-old roots. Ethanol was also present at all of the ages tested except for 16-month-old roots. Hexanal appeared at the three youngest aged roots, and $\alpha$-pinene was determined intermittently in the 9and 24-month-old roots. 
Table 1. Percentage of area and retention time of volatiles collected by SPME and identified by GC-MS from red clover roots of different ages.

\begin{tabular}{lcccccc}
\hline Compound & Retention time (min) & 5 months & 9 months & 11 months & 16 months & 24 months \\
\hline Ethanol & 1.07 & 2.28 & 0.49 & 13.64 & n. d. & 2.44 \\
Hexanal & 3.28 & 22.15 & 4.9 & 10.56 & n. d. & n. d. \\
E-2-Hexenal & 4.19 & 8.97 & n. d. & n. d. & n. d. & n. d. \\
$\alpha-$-pinene & 6.5 & n. d. & 0.63 & n. d. & n. d. & 4.82 \\
3-Octanone & 7.53 & 5.15 & 7.58 & 2.12 & 3.81 & n. d. \\
Limonene & 8.87 & n. d. & n. d. & n. d. & 0.25 & 6.3 \\
\hline
\end{tabular}

n. d.: not detected

Males and females of $H$. obscurus responded similarly to the stimulus in the EAG assays, but clear differences appeared in the behavioral assays. The relative EAG responses of the studied compounds, using ethanol as a reference, are reported in Figure 1. In males, the relative responses can be separated into three different groups. E-2-hexenal and hexanal showed the highest responses, and with the exception of $S$ - $\alpha$-pinene, the responses to the remaining compounds were significantly different from the response to air. In females, the responses followed the same pattern, but all of the tested compounds were significantly different from air, and $E$-2-hexenal and hexanal were the most active compounds.

Behaviorally, males and females of $H$. obscurus responded differently (Fig. 3). Females appeared to be more sensitive to hexanal, $R$-limonene and $S$-limonene than males, which did not respond to the $R$ - isomer of limonene. Meanwhile, ethanol only elicited a response in females, and it could be either an attractant or a repellent depending on the dose. In total, females responded to six of the eight tested compounds at one or more of the doses tested. In contrast, males responded to only three of the eight tested compounds.

\section{Discussion}

Of the compounds found by SPME trapping, E-2-hexenal has been reported in red clover plants as a volatile released from the aerial parts (Buttery et al., 1984) and the roots (Tapia et al., 2007) together with $\alpha$-pinene and limonene, whereas the presence of 3-octanone in roots was established by Kamm and Buttery (1984).

Although most of the volatiles found in the current study are similar to those reported previously, clear differences appeared, even when plants of the same age were compared. These differences may be attributed, in part, to the methods employed to collect the samples. The SPME procedure applied in the current study was conducted at room temperature and atmospheric pressure. Thus, the analytes are adsorbed by simple contact with the fiber, and the result depends on the rate at which the components are released from the matrix (Cornu et al., 2001). These conditions are different than those applied by Tapia et al. (2007), who used supercritical fluid extraction. In this method, the controlled conditions, such as temperature, pressure, type and percentage of modifiers, influence the obtained results (Herrero 
et al., 2010). Furthermore, the absence of a solvent in SPME may be responsible for the different profiles of compounds reported here compared to those reported by Tapia et al. (2007). For example, the retention time of ethanol (Table 1) is similar to the retention time of the solvent used in other studies, explaining why this compound was not recovered in studies using solvent-based methods. On the other hand, Kigathi et al. (2009), noted differences in the volatile profiles of compounds emitted by red clover plants after herbivory as well as under laboratory and field conditions, and they attributed those results to the differences in growing conditions and sampling times.

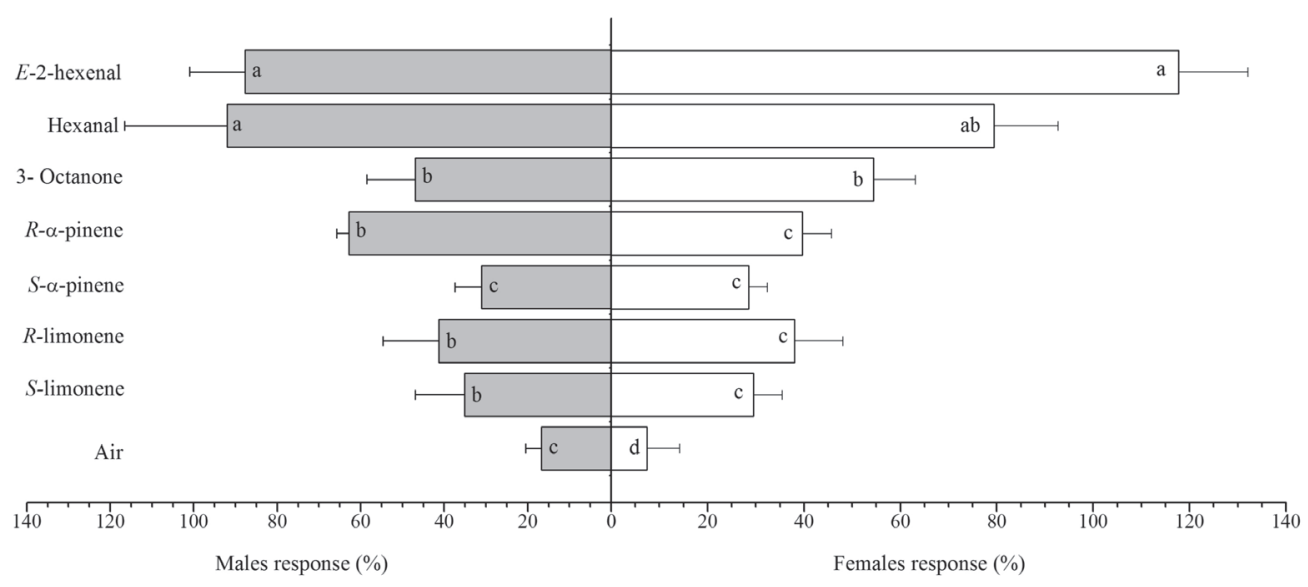

Figure 1. Electroantennographic response of Hylastinus obscurus to different compounds found in red clover roots. The values are expressed as relative percentages $(+\mathrm{SE})$ with respect to the ethanol response. Different letters next to the same sex indicate statistical differences $(p<0.05)$ as determined by the Conover-Inman nonparametric test for multiple comparison for $\mathrm{n}=5$.

To our knowledge, this study is the first record of ethanol being emitted from the roots of red clover. The EAG response and behavioral assays indicate its potential value as a semiochemical. Ethanol has been noted as a fermentation indicator during host colonization by bark beetles (Byers, 1989). Scolytids, which do not use aggregation pheromone to attack their hosts, are frequently strongly attracted to their hosts by monoterpenes, ethanol or a combination of both (Vrkocová et al., 2000). Stressed branches of Douglas-fir (Pseudotsuga menziesii) containing two or three orders of magnitude larger amounts of etha- nol than non-stressed branches, attracted significantly higher numbers of Scolytus unispinosus (Kelsey and Joseph, 2001). In addition, Joseph et al. (2001) showed the effect of ethanol in the effectiveness of traps lured to collect bark beetles, and high release rates of ethanol increased the number of Dendroctonus valens, Hylurgops sp. and Hylastes sp. captured in combination with other kairomones in pine forests.

Hexanal was released from 5-, 9- and 11-monthold roots, but it was not detected in 16- and 24-monthold roots. This compound was behaviorally inactive 
for males, but all of the tested doses repelled females as effectively as $R$-limonene and $S$-limonene. Shown to be a green-leaves volatile by Thiéry and MarionPoll (1998), the inclusion of hexanal did not significantly reduce the attractiveness of traps baited with pheromones from Conophthorus resinosae (de Groot and MacDonald, 1999) and Ips pini (Huber et al., 2001). In fact, Jaffé et al. (1993) showed that hexanal synergized a mix of different pineapple and coconut volatiles, which attracted palm weevils, Rhynchophorus palmarum, in laboratory assays, but not in field tests. Earlier, the presence of hexanal was noted in alfalfa by Buttery et al. (1982), and it was tested in laboratory as a possible attractant for Hylastinus $o b$ scurus, but no positive results were found (Kamm and Buttery, 1984).
Octanone appeared in all the roots sampled, except those from 24-month-old plants. Mixed effects have been attributed to this compound. Thus, it has been reported as a secondary odorant to the strawberry blossom weevil, Anthonomus rubi (Bichão et al., 2005). However, Ramachandran et al. (1991) noted that 3-octanone released from the larval frass of Pseudoplusia includens that fed on soybean plants attracted its natural parasitoid, Microplitis demolitor. In the current study, this compound, which is electrophysiologically perceived by male and females of $H$. obscurus (Fig. 2), did not elicit behavioral activity except in females exposed to the highest dose. This result agrees with the report of Pfeil and Mumma (1993), who observed that high doses of 3-octanone seemed to produce deterrency in females of the phorid fly, Megaselia halterata.

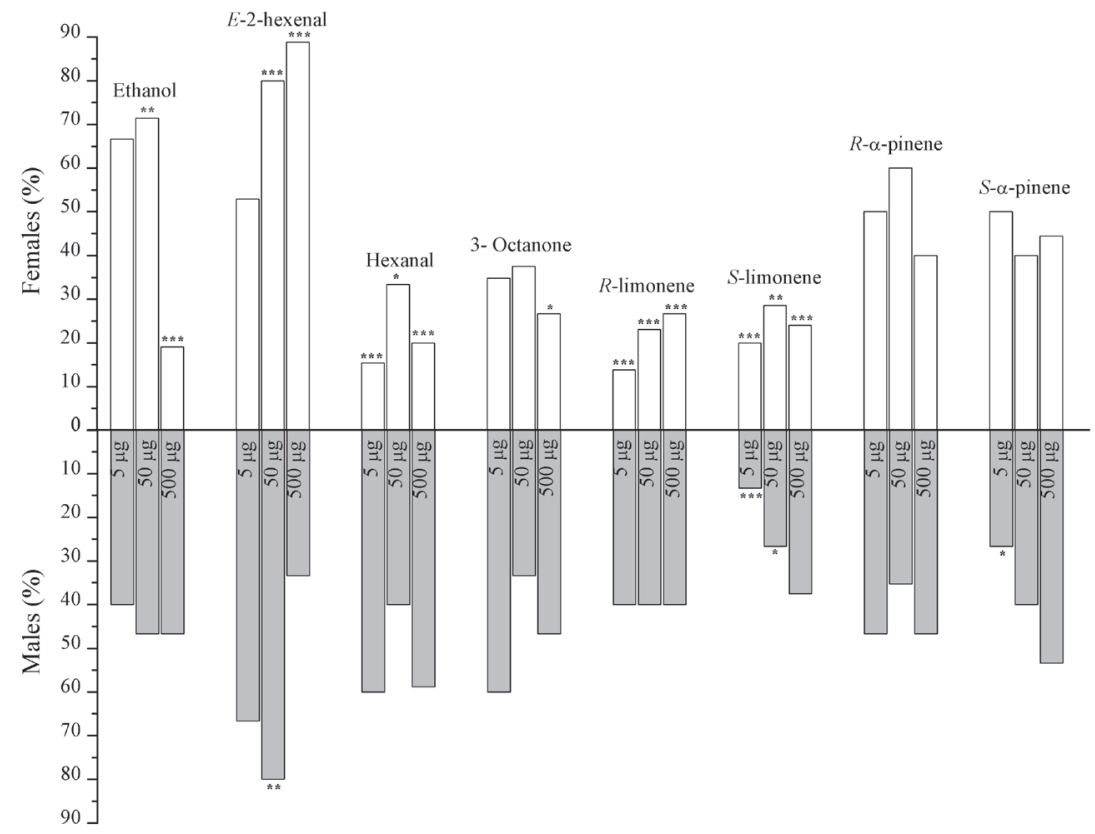

Figure 2. Response (\%) of H. obscurus males and females to three doses of different odorant stimuli in a Y-tube olfactometer. One, two and three asterisks indicate statistical significance according to a G-Test for $p<0.1, p<0.05$ and $p<0.01$, respectively, with $\mathrm{n} \geq 15$. 
The results showed the repellent activity of limonene, establishing clear differences between males and females of $H$. obscurus with respect to the enantiomers of this compound (Figure 2). While all of the tested doses of $R$-limonene and $S$-limonene elicited a repellent response from females, only $S$-limonene produced the same effect in males at two of the three tested doses. Similar effects were noted by Tapia et al. (2007), although isomers and sexes were not discriminated. Wibe et al. (1998) reported that receptor neurons from Hylobius abietis responded differently to the two isomers of limonene, and Mutis et al. (2010) showed that only the $R$-limonene enantiomer was electroantennographically active to males of Aegorhinus superciliosus and able to attract them in laboratory bioassays, in the same manner that volatile extract from females did. Under field conditions, males and females of Conophthorus coniperda were attracted to traps containing both enantiomers of limonene (Miller, 2007). Moreover, the release rate of limonene was directly proportional to the numbers of beetles caught in traps baited with their sexual pheromone.

In the current report, with the exception of the lowest dose of $S$ - $\alpha$-pinene on males, neither isomer was olfactometrically active. In this case, the apparent opposition between behavioral and electrophysiological responses resembles the report of White and Hobson (1993), who found opposite responses in the EAG bioassays and field results when studying the response of Dendroctonus ponderosa toward chiral monoterpenes from ponderosa pine.

The EAG assays showed large relative responses to $E$-2-hexenal as well as the attraction behavior elicited on males and females of Hylastinus obscurus that was established in the behavioral assays. The attractant role of this compound has previously been reported in different scolytids (Huber et al., 2000) and is similar to the report of Tapia et al. (2007) for red clover borer, although they did not discriminate the effect by sex.

\section{Conclusions}

According to the current results, the application of the SPME technique made it possible to add ethanol and hexanal to the range of compounds with promising activity that should be confirmed under field conditions. The stronger response of females to the stimuli compared to males in the behavioral assays may be related to their need to find a suitable host for their offspring.

\section{Acknowledgments}

Rubén Palma thanks the Conicyt project AT24090126 for support, and Andrés Quiroz thanks the Fondecyt project 1100812, which provided funding that made this research possible.

We gratefully acknowledge to the Laboratory of Renewable Resources, Universidad de Concepción, for its kind loan of electroantennographic device.

\section{References}

Aguilera, A., Cisternas, E., Gerding, M., Norambuena, H. 1996. Plagas de las praderas. In: I. Ruiz (ed.), Praderas para Chile, Ministerio de Agricultura, Chile, pp. 310-339.

Alarcón, D., Ortega, F., Perich, F., Pardo, F., Parra, L., Quiroz, A. 2010. Relationship between radical infestation of Hylastinus obscurus (Marsham) and the yield of cultivars and experimental lines of red clover (Trifolium pratense L.). Revista de la Ciencia del Suelo y Nutrición Vegetal 10, 115-125.

Babushok, V. I., Linstrom, P. J., Reed, J. J., Zenkevich, I. G., Brown, R. L., Mallard, W. G., Stein, S. E. 2007. Development of a database of gas chromatographic retention properties of organic compounds. Journal of Chromatography. A 1157, 414-21. 
Bichão, H., Borg-Karlson, A.-K., Araújo, J., Mustaparta, H. 2005. Five types of olfactory receptor neurons in the strawberry blossom weevil $\mathrm{An}$ thonomus rubi: selective responses to inducible host-plant volatiles. Chemical Senses 30, 153-170.

Buttery, R. G., Kamm, J. A., Ling, L. C. 1982. Volatile components of alfalfa flowers and pods. Journal of Agricultural and Food Chemistry 30, 739-742.

Buttery, R. G., Kamm, J. A., Ling, L. C. 1984. Volatile components of red clover leaves, flowers, and seed pods: possible insect attractants. Journal of Agricultural and Food Chemistry 32, 254-256.

Byers, J. A. 1989. Chemical ecology of bark beetles. Experientia 45, 271-283.

Conover, W. 1999. Practical Nonparametric Statistics. Wiley, New York, 587 p.

Cornu, A., Carnat, A. P., Martin, B., Coulon, J. B., Lamaison, J. L., Berdagué, J. L. 2001. Solid-phase microextraction of volatile components from natural grassland plants. Journal of Agricultural and Food Chemistry 49, 203-209.

de Groot, P., MacDonald, L. M. 1999. Green leaf volatiles inhibit response of red pine cone beetle Conophthorus resinosae (Coleoptera: Scolytidae) to a sex pheromone. Naturwissenschaften 86 , $81-85$.

Herrero, M., Mendiola, J. A, Cifuentes, A., Ibáñez, E. 2010. Supercritical fluid extraction: Recent advances and applications. Journal of Chromatography A 1217, 2495-2511.

Huber, D. P., Borden, J. H., Stastny, M. 2001. Response of the pine engraver, Ips pini (Say) (Coleoptera: Scolytidae), to conophthorin and other angiosperm bark volatiles in the avoidance of non-hosts. Agricultural and Forest Entomology 3, 225-232.

Huber, D. P., Gries, R., Borden, J. H., Pierce Jr., H. D. 2000. A survey of antennal responses by five species of coniferophagous bark beetles (Coleop- tera: Scolytidae) to bark volatiles of six species of angiosperm trees. Chemoecology 10, 103-113.

Jaffé, K., Sánchez, P., Cerda, H., Hernández, J. V., Jaffé, R., Urdaneta, N., Guerra, G., Martínez, R., Miras, B. 1993. Chemical ecology of the palm weevil Rhynchophorus palmarum (L.) (Coleoptera: Curculionidae): Attraction to host plants and to a male-produced aggregation pheromone. Journal of Chemical Ecology 19, 1703-1720.

Jeanbourquin, P., Guerin, P. M. 2007. Sensory and behavioural responses of the stable fly Stomoxys calcitrans to rumen volatiles. Medical and Veterinary Entomology 21, 217-24.

Joseph, G., Kelsey, R. G., Peck, R. W., Niwa, C. G. 2001. Response of some scolytids and their predators to ethanol and 4-allylanisole in pine forests of central Oregon. Journal of Chemical Ecology 27, 697-715.

Kamm, J. A., Buttery, R. G. 1984. Root volatile components of red clover: identification and bioassay with the clover root borer (Coleoptera: Scolytidae). Environmental Entomology 13, 1427-1430.

Kelsey, R, Joseph, G. 2001. Attraction of Scolytus unispinosus bark beetles to ethanol in waterstressed Douglas-fir branches. Forest Ecology and Management 144, 229-238.

Kigathi, R. N., Unsicker, S. B., Reichelt, M., Kesselmeier, J., Gershenzon, J., Weisser, W. W. 2009. Emission of volatile organic compounds after herbivory from Trifolium pratense (L.) under laboratory and field conditions. Journal of Chemical Ecology 35, 1335-1348.

Leath, K., Byers, R. 1973. Attractiveness of diseased red clover roots to the clover root borer. Phytopathology 63, 428-431.

Manosalva, L. 2010. Estudio de la composición química de extractos de raíces de líneas y cultivares de plantas jóvenes de trébol rosado (Trifolium pratense L.) y su relación con la respuesta con- 
ductual del insecto Hylastinus obscurus (Marsham). Tesis de Magíster, Universidad de La Frontera, Chile, $62 \mathrm{p}$.

Matamala, J. 1976. Biología, niveles de infestación, daño y combate químico de Hylastinus obscurus (Marsham) (Coleoptera: Scolytidae). Bachelor thesis, Universidad Austral de Chile, 51 p.

Mendesil, E., Bruce, T. J. a, Woodcock, C. M., Caulfield, J. C., Seyoum, E., Pickett, J. 2009. Semiochemicals used in host location by the coffee berry borer, Hypothenemus hampei. Journal of Chemical Ecology 35, 944-950.

Miller, D. R. 2007. Limonene: attractant kairomone for white pine cone beetles (Coleoptera: Scolytidae) in an eastern white pine seed orchard in western North Carolina. Journal of Economic Entomology $100,815-822$.

Mutis, A., Parra, L., Manosalva, L., Palma, R., Candia, O., Lizama, M., Pardo, F., Perich, F., Quiroz, A. 2010. Electroantennographic and behavioral responses of adults of raspberry weevil Aegorhinus superciliosus (Coleoptera: Curculionidae) to odors released from conspecific females. Environmental Entomology 39, 1276-1282.

Pfeil, R. M., Mumma, R. O. 1993. Bioassay for evaluating attraction of the phorid fly, Megaselia halterata to compost colonized by the commercial mushroom, Agaricus bisporus and to 1-octen-3-ol and 3-octanone. Entomologia Experimentalis et Applicata 69, 137-144.

Pruess, K. P., Weaver, C. R. 1958. Estimation of red clover yield losses caused by the clover root borer. Journal of Economic Entomology, 51, 491-492.

Quiroz, A., Ortega, F., Ramírez, C. C., Wadhams, L. J., Pinilla, K. 2005. Response of the beetle Hylastinus obscurus Marsham (Coleoptera: Scolytidae) to red clover (Trifolium pratense L.) volatiles in a laboratory olfactometer. Environmental Entomology 34, 690-695.
Ramachandran, R., Norris, D. M., Phillips, J. K., Phillips, T. W. 1991. Volatiles mediating plantherbivore-natural enemy interactions: soybean looper frass volatiles, 3-octanone and guaiacol, as kairomones for the parasitoid Microplitis demolitor. Journal of Agricultural and Food Chemistry $39,2310-2317$.

Rochat, D., Ramirez-Lucas, P., Malosse, C., Aldana, R., Kakul, T., Morin, J. P. 2000. Role of solidphase microextraction in the identification of highly volatile pheromones of two Rhinoceros beetles Scapanes australis and Strategus aloeus (Coleoptera, Scarabaeidae, Dynastinae). Journal of Chromatography A 885, 433-444.

Schoonhoven, L., van Loon, J., Dicke, M. 2005. Insect-Plant Biology. Oxford University Press, New York, $421 \mathrm{p}$.

Sokal, R., Rohlf, F. 2005. Biometry. W. Freeman, New York, $887 \mathrm{p}$.

Steiner, J., Alderman, S. 1999. Red clover seed production. V. Root health and crop productivity. Crop Science 39, 1407-1415.

Steiner, J., Alderman, S. 2003. Red clover seed production. VI. Effect and economics of soil $\mathrm{pH}$ adjusted by lime application. Crop Science 43, 624-630.

Syed, Z, Guerin, P. M., Baltensweiler, W. 2003. Antennal responses of the two host races of the larch bud moth, Zeiraphera diniana, to larch and cembran pine volatiles. Journal of Chemical Ecology 29, 1691-1708.

Syed, Zainulabeuddin, Leal, W. S. 2007. Maxillary palps are broad spectrum odorant detectors in $\mathrm{Cu}$ lex quinquefasciatus. Chemical Senses 32, 727738.

Tapia, S., Pardo, F,. Perich, F., Quiroz, A. 2005. Clover root borer Hylastinus obscurus (Marsham) (Coleoptera: Scolytidae) has no preference for volatiles from root extracts of disease infected 
red clover. Acta Agriculturae Scandinavica B 55, 158-160.

Tapia, T., Perich, F, Pardo, F, Palma, G., Quiroz, A. 2007. Identification of volatiles from differently aged red clover (Trifolium pratense) root extracts and behavioural responses of clover root borer (Hylastinus obscurus) (Marsham) (Coleoptera: Scolytidae) to them. Biochemical Systematics and Ecology 35, 61-67.

Thiéry, D., Marion-Poll, F. 1998. Electroantennogram responses of Douglas-fir seed chalcids to plant volatiles. Journal of Insect Physiology 44, 483-490.

Vrkocová, P., Valterová, I., Vrkoc, J., Koutek, B. 2000. Volatiles released from oak, a host tree for the bark beetle Scolytus intricatus. Biochemical Systematics and Ecology 28, 933-947.
White, P. R., Hobson, K. R. 1993. Stereospecific antennal response by red turpentine beetle, Dendroctonus valens to chiral monoterpenes from ponderosa pine resin. Journal of Chemical Ecology 19, 2193-2202.

Wibe, A., Borg-Karlson, A. K., Persson, M., Norin, T., Mustaparta, H. 1998. Enantiomeric composition of monoterpene hydrocarbons in some conifers and receptor neuron discrimination of $\alpha$-pinene and limonene enantiomers in the pine weevil, $H y$ lobius abietis. Journal of Chemical Ecology 24, 273-287.

Zhang, Z., Pawliszyn, J. 1995. Quantitative extraction using an internally cooled solid phase microextraction device. Analytical Chemistry 67, 34-43. 
